УДК 629.4.027

Д-р техн. наук І.Е. Мартинов (УкрДАЗТ), інэн. В.М. Ільчишин (ДП Укррефтранс), махістрант А.П. Семененко (УкрДАЗТ)

\title{
АНАЛІЗ ТЕХНІЧНОГО СТАНУ БУКСОВИХ ВУЗЛІВ КРИТИХ ВАНТАЖНИХ ВАГОНІВ
}

\begin{abstract}
Постановка проблеми у загальному вигляді, іiї зв'язок 3 важливими науковими та практичними завданнями. Аналіз випадків порушень безпеки руху у вагонному господарстві свідчить, що технічний стан елементів буксових вузлів вантажних вагонів суттєво впливає на безпеку руху поїздів. Понад $50 \%$ відчеплень вагонів на шляху прямування викликані відмовами роликових букс.
\end{abstract}

He підлягає сумніву, що найважливішим елементом буксового вузла $\epsilon$ підшипник. Для забезпечення надійної i безвідмовної роботи буксових вузлів вантажних вагонів 3 підшипниками кочення необхідно вивчити причини виникнення пошкоджень буксових підшипників, встановити різні експлуатаційні та інші фактори, що впливають на їх безаварійну роботу. Встановлення причин виходу 3 ладу підшипників дозволяє визначити напрямок подальших робіт з їх усунення.

Підвищення вимог до якості підшипників обумовлено необхідністю точної кількісної оцінки надійності їх роботи. Ці оцінки можуть бути отримані лише шляхом випробування підшипників на надійність. На основі таких досліджень знаходиться закон розподілу відмов даного типу підшипників. Також знання закону розподілення дозволить створити науковообгрунтовану систему ремонту та технічного обслуговування буксових підшипникових вузлів.

Аналіз останніх досліджень i публікацій. Проблема підвищення надійності елементів буксових вузлів неодноразово розглядалася науковцями i фахівцями залізничного транспорту впродовж останніх десятиліть. Питанням статистичної оцінки надійності підшипників кочення загального призначення присвячені дослідження М.3. Народецького [2].

Вибору найбільш ефективної конструкції підшипників для букс рухомого складу присвячена стаття [8]. Досвід експлуатації циліндричних підшипників в буксах вантажних і пасажирських вагонів аналізується в роботах $[1,7]$.

В статті [3] розглядаються особливості розрахунку показників надійності підшипників вантажних вагонів 3 урахуванням знеособленого характеру експлуатації.

Причини недостатньої надійності елементів букс вагонів аналізуються в дослідженнях $[4,5,6]$.

Але в попередніх дослідженнях не враховувались умови експлуатації, так як раніше експлуатація підшипників була знеособлена. В умовах сьогоднішньої експлуатації, коли вантажні вагони $\epsilon$ власністю певних підприємств та повертаються для проведення ремонту на свої підприємства, стало можливим більш точно оцінити технічний стан та визначити надійність циліндричних підшипників буксових вузлів вантажних вагонів.

Метою дослідження $є$ аналіз відмов циліндричних роликових підшипників буксових вузлів вантажних критих вагонів.

Основна частина. Для розв'язання зазначеної задачі був виконаний аналіз журналів форми ВУ-91, в яких зазначаються пошкодження буксових підшипників.

Для аналізу надійності підшипників використовувалися дані Державного 
підприємства "Український державний центр залізничних рефрижераторних перевезень "Укррефтранс" за період з січня по серпень 2012 року.

Всього була оброблена інформація майже про шістнадцять тисяч підшипників.

Всі несправності деталей підшипників були розділені на такі групи:
- дефекти втомного походження (раковини, лущення);

- корозійні пошкодження;

- дефекти раптового походження (злами, тріщини, відколи);

- пошкодження сепараторів.

Основні результати обробки подано в таблиці.

Таблиця

Розподіл підшипників за видами несправностей

\begin{tabular}{|l|c|c|}
\hline \multicolumn{1}{|c|}{ Несправності } & $\begin{array}{c}\text { \% до числа } \\
\text { оглянутих }\end{array}$ & $\begin{array}{c}\text { \% до числа } \\
\text { пошкоджених }\end{array}$ \\
\hline раковини від утоми на доріжці кочення & 0,68 & 0,82 \\
\hline корозійні раковини на поверхні кочення & 5,8 & 7,03 \\
\hline корозійні раковини на поверхні кочення ролика & 5,2 & 6,37 \\
\hline тріщини бортів зовнішнього кільця & 0,2 & 0,31 \\
\hline тріщини зовнішнього кільця & 0,01 & 0,01 \\
\hline задири (ялинка) на бортах кільця & 9,68 & 11,70 \\
\hline задири (ялинка) на торцях ролика & 4,89 & 5,92 \\
\hline вм'ятини на доріжці кочення зовнішнього кільця & 0,01 & 0,02 \\
\hline вм'ятини на доріжці кочення ролика & 4,26 & 5,15 \\
\hline поверхнева корозія на доріжці кочення & 50,91 & 61,55 \\
\hline поверхнева корозія на доріжці кочення & 0,02 & 0,02 \\
\hline поверхнева корозія на доріжці кочення ролика & 0,86 & 1,04 \\
\hline сліди перегрівання на зовнішньому кільці & 0,05 & 0,06 \\
\hline
\end{tabular}

В результаті обробки отриманої інформації встановлено, що 85 \% оглянутих підшипників мають пошкодження різного ступеня тяжкості, 3 яких $2 \%$ оглянутих підшипників не підлягають відновленню.
Аналіз отриманих даних свідчить про те, що найбільш часто 3 ладу виходять зовнішні кільця - $70 \%$. Підшипники виявляються несправними через виход 3 ладу роликів - у 18 \% випадків, а внутрішні кільця несправні - у $12 \%$ (рис. 1).

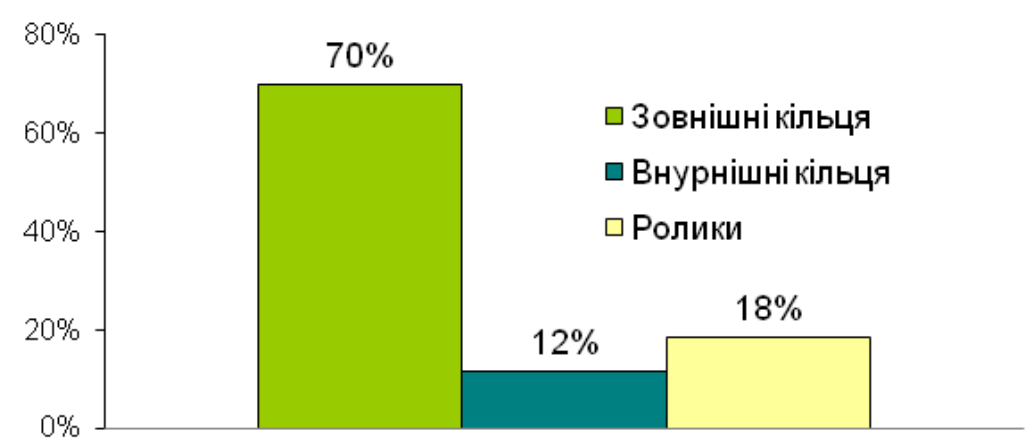

Рис. 1. Співвідношення між пошкодженими деталями підшипників 


\begin{tabular}{|c|c|}
\hline причиною & постачальниками \\
\hline несправності підшипників $\epsilon$ корозія - & підшипників є Свропейська підшипникова \\
\hline $\begin{array}{l}\text { Отримані дані дозволяють також } \\
\text { порівняти якість буксових підшипників, } \\
\text { виготовлених на різних заводах. Відомо, }\end{array}$ & $\begin{array}{ll}\text { Степногірськ, } & \text { Казахстан, та } \\
\text { "Харківський } \\
\text { (рис. 2). }\end{array}$ \\
\hline
\end{tabular}

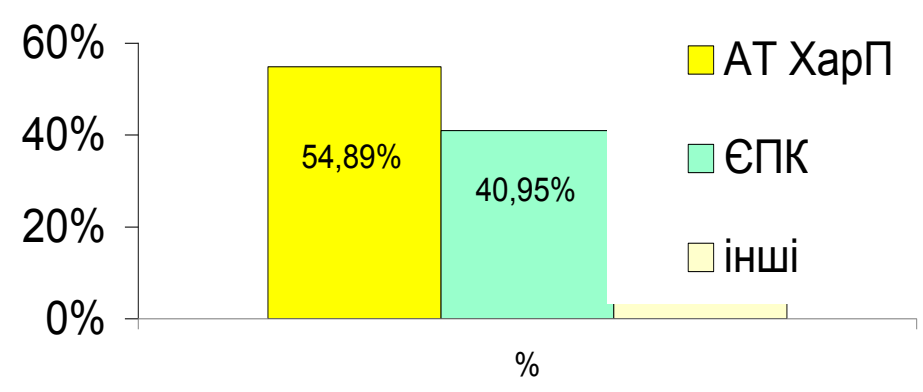

Рис. 2. Співвідношення оглянутих підшипників у залежності від виробника

Кількість справних і пошкоджених підшипників різних заводів-виробників суттєво не відрізняється.

Так само процентне співвідношення основних причин виходу 3 ладу підшипників практично однакове для виробників АТ ХарП та ЄПК.

Висновки 3 дослідження i перспективи, подальший розвиток $\mathbf{y}$ даному напрямку. Під час досліджень був проаналізований технічний стан циліндричних роликових підшипників буксових вузлів вантажних вагонів. На основі отриманих даних можна зробити висновок, що дана конструкція підшипників кочення не $\epsilon$ досконалою i вона не відповідає сучасним вимогам експлуатації рухомого складу, оскільки не виконується головна вимога - забезпечення сприйняття радіальних i осьових сил в режимі тертя кочення.

Результати обстежень дають можливість у подальшому визначити закон розподілення напрацювання до відмови буксових підшипників.

\section{Список літератури}

1. Девятков, В.Ф. Опыт эксплуатации буксовых узлов с роликовыми подшипниками вагонов грузового и пассажирского парка [Текст] / В.В. Девятков, В.В. Абашкин // Вопросы перевода подвижного состава на роликовые подшипники: тр. ВНИИЖТ. - М.: Транспорт, 1961. - Вып. 221. - С. 16-24.

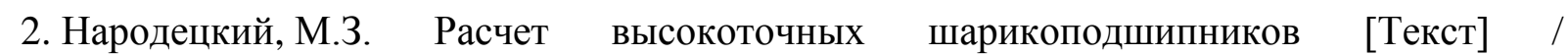
М.3. Народецкий, М.П. Ковалев. - М.: Машиностроение, 1975. - 280 с.

3. Покровский, Б.Н. К постановке вопроса об оценке надежности подшипников качения букс вагонов [Текст] / Б.Н. Покровский // Всесоюзный заочный институт инженеров транспорта: сб. науч. трудов. - М., 1978. - Вып. 97. - С. 41-49.

4. Мартынов, И.Э. Анализ опыта эксплуатации цилиндрических роликоподшипников букс грузовых вагонов [Текст] / И.Э. Мартынов // Вісник Східноукраїнського державного університету. - Луганськ, 2000. - № 5 (27). - С. 157-159. 
5. Мартынов, И.Э. К проблеме совершенствования подшипникового узла вагонов [Текст] / А.П. Горбенко, А.В. Донченко, И.Э. Мартынов // Залізничний транспорт України. 1999. - № 6. - C. 39-42.

6. Цюренко, В.Н. Надежность роликових подшипников в буксах вагонов [Текст] / В.Н. Цюренко, В.А. Петров. - М.: Транспорт, 1982. - 96 с.

7. Цюренко, В.Н. Опыт эксплуатации вагонов с буксовими узлами на подшипниках качения [Текст] / В.Н. Цюренко // Пути совершенствования конструкций буксовых узлов вагонов с подшипниками качения: тр. ВНИИЖТ. - М.: Транспорт, 1982. - Вып. 654. - С. 4-26.

8. Чебаненко, В.М. К вопросу выбора рациональной конструкции вагонной роликовой буксы [Текст] / В.М. Чебаненко // Техника железнодорожных дорог. - 1952. - № 7. - С. 11-16.

Ключові слова: буксовий вузол, роликовий підшипник, пошкодження, корозія, раковини від утоми.

\section{Анотації}

Виконаний аналіз технічного стану циліндричних підшипників кочення буксових вузлів вантажних вагонів. Проаналізовані основні причини, що викликають відмови.

Выполнен анализ технического состояния цилиндрических подшипников качения буксовых узлов грузовых вагонов. Проанализированы причины, вызывающие отказы.

The analysis of the technical state of cylindrical roller bearings of axle boxes of freight cars. Analyzed the causes of failures. 